\title{
COMPARATIVE PHYLOGENETIC ANALYSIS OF NEISSERIA GONORRHOEAE CLINICAL ISOLATES IN RUSSIA, EUROPEAN UNION, AND JAPAN
}

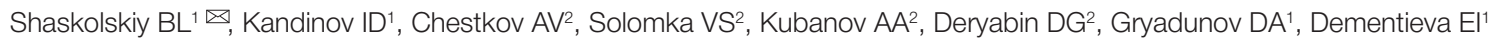

${ }^{1}$ Center for Precision Genome Editing and Genetic Technologies for Biomedicine, Engelhardt Institute of Molecular Biology, Russian Academy of Sciences, Moscow, Russia

2 State Research Center of Dermatovenerology and Cosmetology, Russian Ministry of Health, Moscow, Russia

\begin{abstract}
Surveillance of multidrug-resistant infections is a priority task for contemporary epidemiology. The aim of this study was to genotype modern clinical isolates of N. gonorrhoeae using the NG-MAST technique (Neisseria gonorrhoeae multi-antigen sequence typing) and to compare the phylogeny of the gonococcal pathogens coming from Russia, European Union and Japan. We studied a total of 822 isolates collected in Russia from 2013 through 2018. We also used NG-MAST data from the following databases: PathogenWatch (European Union, 1,071 isolates) and PubMLST (Japan, 206 isolates). Russian isolates represented 301 different NG-MAST types. The most common were types 807, 228, 1993, 5714, and 9476 (8.3\%, 3.3\%, 3.2\%, 3.2\%, and 2.7\%, respectively). There were only 3 isolates $(0.4 \%)$ from Russia that represented the epidemiologically significant sequence type 1407 prevailing in many countries and characterized by multiple determinants of antimicrobial resistance. A phylogenetic tree for the NG-MAST types found in Russia and European countries was constructed. The cluster analysis of the proportion of isolates belonging to unique sequence types and the country population size allowed us to identify 2 clusters (significance level -0.01 ): the first cluster included Russia and Japan, the second, European countries. A distribution pattern was identified for unique sequence types: the greater is the population size, the higher is their proportion. The phylogenetic analysis demonstrated a genetic distance between the most common Russian, European and Japanese sequence types, suggesting that the Russian population of N. gonorrhoeae has been evolving relatively locally.
\end{abstract}

Keywords: Neisseria gonorrhoeae, NG-MAST, phylogenetic analysis

Funding: the study was supported by the Russian Science Foundation (Project 17-75-20039 on the assessment of genetic diversity of sequence types) and the Ministry of Science and Higher Education of the Russian Federation (Agreement № 075-15-2019-1660 on the collection and verification of clinical isolates and the establishment of the association between the unique sequence types and the population size). The isolates were sequenced at the facilities of the Genome center for collective use (Engelhardt Institute of Molecular Biology; http://www.eimb.ru/ru1/ckp/ccu_genome_c.php).

Author contribution: Shaskolskiy BL, Dementieva El, Kandinov ID carried out the study, analyzed the data and wrote the manuscript; Gryadunov DA supervised the study and wrote the manuscript; Chestkov AV, Solomka VS, Kubanov AA, Deryabin DG collected and verified clinical isolates, analyzed the obtained data.

Compliance with ethical standards: the study was approved by the Ethics Committee of the State Research Centre of Dermatovenerology and Cosmetology (Protocol № 11, dated November 29, 2019). Specimens were collected in compliance with the Declaration of Helsinki (2000) and the European Convention on Human Rights and Biomedicine (1999).

$\triangle$ Correspondence should be addressed: Boris L. Shaskolskiy Vavilova, 32, Moscow, 119991; b.shaskolskiy@biochip.ru

Received: 09.01.2020 Accepted: 08.02.2020 Published online: 21.02.2020

DOI: 10.24075/brsmu.2020.009

\section{СРАВНИТЕЛЬНЫЙ ФИЛОГЕНЕТИЧЕСКИЙ АНАЛИЗ КЛИНИЧЕСКИХ ИЗОЛЯТОВ NEISSERIA GONORRHOEAE РОССИИ, СТРАН ЕВРОСОЮЗА И ЯПОНИИ}

\section{Б. Л. Шаскольский ${ }^{1}$, И. Д. Кандинов ${ }^{1}$, А. В. Честков², В. С. Соломка², А. А. Кубанов², Д. Г. Дерябин², Д. А. Грядунов ${ }^{1}$ Е. И. Дементьева}

${ }^{1}$ Центр высокоточного редактирования и генетических технологий для биомедицины, Институт молекулярной биологии имени В. А. Энгельгардта Российской академии наук, Москва, Россия

2 Государственный научный центр дерматовенерологии и косметологии Минздрава России, Москва, Россия

\begin{abstract}
Мониторинг возбудителей инфекционных заболеваний, развивающих множественную устойчивость к антимикробным препаратам, является важной и актуальной задачей. Целью работы являлось генотипирование современных российских клинических изолятов N. gonorrhoеае по протоколу NG-MAST (Neisseria gonorrhoeae multi-antigen sequence types) и сравнительный филогенетический анализ возбудителя гонококковой инфекции в России, странах ЕС и Японии. Всего исследовано 822 изолята, собранных в РФ в период с 2013 по 2018 гг. Использовали также данные NG-MAST-типирования из баз данных «PathogenWatch» (страны EC, 1071 образец) и «PubMLST» (Япония, 206 образцов). Изоляты РФ принадлежали к 301 различному NG-MAST типу, наиболее распространенными являлись 807, 228, 1993, 5714, 9476 (8,3\%; 3,3\%; 3,2\%; 3,2\%; 2,7\% соответственно). В РФ обнаружено только 3 изолята (0,4\%) пандемически значимого NG-MAST 1407, характеризующегося множественными детерминантами резистентности к антимикробным препаратам и доминирующего во многих странах мира. Построено филогенетическое древо NG-MAST типов, найденных в России и в европейских странах. Кластерный анализ данных по доле изолятов с уникальными сиквенс-типами и численности населения показал существование двух кластеров (уровень значимости 0,01): первый составили Россия и Япония, второй - европейские страны. Показана тенденция в распределении уникальных сиквенс-типов - их доля тем выше, чем больше численность населения страны. Филогенетический анализ показал генетическую отдаленность наиболее распространенных российских, европейских и японских сиквенс-типов, что указывает на локальный характер формирования и эволюции российской популяции N. gonorrhoeae.
\end{abstract}

Ключевые слова: филогения Neisseria gonorrhoeae, NG-MAST

Финансирование: работа выполнена при поддержке гранта РНФ 17-75-20039 (оценка генетического разнообразия сиквенс-типов) и Соглашения с Министерством науки и высшего образования РФ № 075-15-2019-1660 (сбор и верификация клинических изолятов, определение соответствия уникальных сиквенс-типов и численности населения). Секвенирование изолятов выполнено в ЦКП «Геном» ИМБ PAH (http://www.eimb.ru/ru1/ckp/ccu_genome_c.php).

Вклад авторов: Б. Л. Шаскольский, Е. И. Дементьева, И. Д. Кандинов - проведение исследования, анализ данных, написание статьи; Д. А. Грядунов организация исследования, работа над рукописью; А. В. Честков, В. С. Соломка, А. А. Кубанов, Д. Г. Дерябин - сбор и верификация клинических изолятов, анализ данных.

Соблюдение этических стандартов: исследование одобрено этическим комитетом Государственного научного центра дерматовенерологии и косметологии (протокол № 11 от 29 ноября 2019 г.). Отбор биологического материала для исследования был произведен с учетом положений Хельсинской декларации ВМА (2000) и протокола Конвенции Совета Европы о правах человека и биомедицине (1999).

$\triangle$ Для корреспонденции: Борис Леонидович Шаскольский ул. Вавилова, д. 32, г. Москва, 119991; b.shaskolskiy@biochip.ru

Статья получена: 09.01.2020 Статья принята к печати: 08.02.2020 Опубликована онлайн: 21.02.2020

DOI: $10.24075 /$ vrgmu.2020.009 
Molecular genetic typing techniques revealing intraspecies variability in pathogenic bacteria have been vigorously used in epidemiological research since the early 21 st century [1]. Genotyping is especially important for the surveillance of multidrug-resistant infections, such as those caused by Neisseria gonorrhoeae. The World Health Organization (WHO) has included $N$. gonorrhoeae in the list of 12 pathogens that pose a global threat and require urgent development of novel antimicrobial drugs [2].

Surveillance of epidemiologically significant clones of N. gonorrhoeae, including multidrug-resistant isolates, and control of their global and regional spread rely on the use of Neisseria gonorrhoeae multi-antigen sequence typing (NGMAST), Multilocus sequence typing (MLST) [3, 4] and wholegenome sequencing (WGS) [5]. WGS provides the most comprehensive information on the phylogeny of clinical isolates, but high costs and strict requirements for the quality of DNA samples still limit its application in routine practice. MLST was originally developed to type $N$. meningitidis and this method analyzes genes that are more conserved than porB and tbpB targeted by NG-MAST. Thus, NG-MAST currently remains the main and the most widely used technique to study the evolution of the pathogen and identify its transmission routes $[4,6]$. Moreover, NG-MAST has demonstrated high resolution in the analysis of clinical isolates [7, 8].

NG-MAST consists in sequencing variable regions of two genes encoding the transmembrane porin protein (porB) and the transferrin-binding protein $(t b p B)$. Based on sequencing data, each unique sequence is assigned a reference allele number, and the combination of allele numbers is assigned a sequence type (ST). The list of the identified alleles is constantly expanding. In January 2020, the database at www.ng-mast. net contained over 11,000 porB alleles and over 2,900 tbpB alleles that formed over 19,500 NG-MAST types.

The aim of this study was the NG-MAST typing of modern N. gonorrhoeae clinical isolates collected in Russia and the comparative phylogenetic analysis of bacteria causing gonococcal infection in Russia, European countries and Japan.

\section{METHODS}

Clinical isolates of $N$. gonorrhoeae (822 specimens) collected in 17 Russian regions under the Russian Gonococcal Antimicrobial Surveillance Programme (RU-GASP) were shipped to the State Research Center for Dermatovenerology and Cosmetology (Moscow). The isolates had been collected in 2013-2018 in 7 of 8 federal districts, except the Far Eastern district, specifically from Arkhangelsk, Astrakhan, Bryansk, Irkutsk, Kaluga, Novosibirsk, Omsk, Penza, Pskov, Ryazan, Tomsk, Chelyabinsk and Stavropol regions, the city of Moscow, the Republics of Tatarstan, Tyva and Chuvash. The specimens came from specialized healthcare facilities for dermatology and venerology (1 specimen per patient). The number of the obtained clinical isolates varied across the regions between 1 and $10 \%$ of the total reported cases of gonococcal infection in a given region (5 to 35 strains a year), depending on the population density and the incidence of the infection. Sample collection, shipment, culture, verification and storage conditions are described in detail in [9-11]. The number of clinical isolates analyzed during each year of our study are provided in Table 1.

Molecular typing of N. gonorrhoeae consisted in sequencing the variable regions of the porB (490 bp) and tbpB (390 bp) genes according to the NG-MAST protocol [12]. After the first round of PCR amplification and purification of PCR products, the resulting DNA fragments were Sanger-sequenced using a 3730xl Genetic Analyzer (Applied Biosystems; USA). The obtained allele sequences were compared to the reference sequences from the NG-MAST database at www.ng-mast. net in order to identify a sequence type of each clinical isolate. Previously uncharacterized allele sequences detected in porB and tbpB or their combinations were submitted to the aforementioned NG-MAST database and assigned an NGMAST sequence type.

Data on N. gonorrhoeae circulating in the European Union were retrieved from EUROGASP database at https://pathogen. watch/collection/eurogasp2013. We analyzed a total of 1,071 isolates from $21 \mathrm{EU}$ countries, including Austria, Belgium, UK,

Table 1. The most common NG-MAST types found in the Russian population (2013-2018)

\begin{tabular}{|c|c|c|c|}
\hline Year & $\begin{array}{l}\text { Number of analyzed clinical isolates } \\
\text { (number of identified sequence types) }\end{array}$ & $\begin{array}{l}\text { The most common } \\
\text { sequence types }\end{array}$ & $\begin{array}{l}\text { Proportion of samples with } \\
\text { a specified sequence type, \% }\end{array}$ \\
\hline \multirow{3}{*}{2013} & \multirow{3}{*}{$160(81)$} & 807 & 13.1 \\
\hline & & $1152^{*}$ & 5.6 \\
\hline & & $5941^{*}$ & 3.7 \\
\hline \multirow{3}{*}{2015} & \multirow{3}{*}{$123(57)$} & $9476^{*}$ & 11.4 \\
\hline & & 807 & 8.1 \\
\hline & & $1544^{*} .571$ & 4.9 \\
\hline \multirow{3}{*}{2016} & \multirow{3}{*}{$261(128)$} & 807 & 6.5 \\
\hline & & $5714^{*}$ & 6.1 \\
\hline & & 1993 & 4.6 \\
\hline \multirow{3}{*}{2017} & \multirow{3}{*}{$127(63)$} & 807 & 10.2 \\
\hline & & $1751^{*}$ & 6.3 \\
\hline & & $13058^{*}$ & 5.5 \\
\hline \multirow{3}{*}{2018} & \multirow{3}{*}{$151(67)$} & $228^{*}$ & 14.6 \\
\hline & & $14942^{*}$ & 5.3 \\
\hline & & 807. 1993. 14020* & 4.6 \\
\hline
\end{tabular}

Note: * NG-MAST types unique to Russia. 
Hungary, Germany, Greece, Denmark, Ireland, Iceland, Spain, Italy, Cyprus, Latvia, Malta, Netherlands, Norway, Portugal, Slovakia, Slovenia, France, and Sweden. NG-MAST data on 206 isolates of $N$. gonorrhoeae circulating in Japan (2015) were retrieved from the database at https://pubmlst.org/ (we selected samples of $N$. gonorrhoeae with known variants of porB and tbpB). Isolates with a mixed or unknown NG-MAST type were excluded from the analysis. A total of 29 isolates were excluded, which amounts to $1.4 \%$ of the initial sample size (EU + Japan).

Phylogenetic analysis was performed on the concatenated sequences of porB and tbpB. Model selection was done using Bayesian and Akaike information criteria. The best substitution model for our dataset was GTR with the calculation of the proportion of invariant sites and the $\mathrm{G}$ model of rate heterogeneity. Based on the obtained sequences and the chosen model, a maximum likelihood phylogenetic tree was constructed in RAxML ver. 7.4.8 [13]. The phylogenetic tree was created using the software at http://galaxy-dev.cnsi.ucsb.edu/ osiris/. The number of iterations applied was 999. The tree was constructed from the data on Russian and European clinical isolates of $N$. gonorrhoeae collected in 2013. For phylogenetic tree clades, bootstrap values of $90 \%$ or above were considered statistically significant.

The data on the population size and the proportion of isolates representing unique sequence types in each country were analyzed using Ward's agglomerative hierarchical clustering procedure in the "cluster» package for $\mathrm{R}$. The optimal number of clusters was computed in the «Nbclust» package for $R$ [14]. Information on the population size in different countries and the net migration rate (number of migrants per 1,000 population) were taken from The World Factbook: https://www. cia.gov/library/publications/the-world-factbook/.

\section{RESULTS}

Based on the results of molecular typing, 822 clinical isolates of N. gonorrhoeae collected in Russia between 2013 and 2018 were attributed to 301 different NG-MAST types. The most prevalent sequence types were $807,228,1993,5714$, and $9476(8.3 \%, 3.3 \%, 3.2 \%, 3.2 \%$, and $2.7 \%$ of the total sample size, respectively). In 2013, isolates of NG-MAST type 807 made up over $13 \%$ of the Russian N. gonorrhoeae population; in the next few years, this number gradually declined, reaching 4.6\% in 2018 (Table 1). Representatives of sequence types 807 and 1993 were also detected among European specimens, but occurred there sporadically: type 807 was found in the Spanish and Slovakian populations, whereas type 1993, in Denmark. In 2018, sequence type 228, which is unique to Russia, was the most common type in Russia, amounting to $14.6 \%$ of the gonococcal population. The proportion of Russian isolates classified as unique Russian sequence types (marked by an asterisk in Table 1) remained constant relative to the total number of isolates analyzed between 2013 and 2018 (80\% on average).

Notably, the proportion of sequence types represented by only one specimen was high and stable over the entire studied period, amounting to $25-31 \%$ of the total number of isolates. In the European population of $N$. gonorrhoeae, it was as high as $24 \%$ in 2013 [6].

Results of $N$. gonorrhoeae molecular typing in European countries $[5,6]$ and the most common sequence types are shown in Table 2. In 2013, 389 sequence types were circulating in the EU, the most prevalent being sequence type 1407, which occurred in 13 countries and constituted $7.3 \%$ of the total analyzed clinical isolates.
The Japanese population of $N$. gonorrhoeae (Table 2) was very different from both Russian and European populations. Japanese isolates represented 65 molecular types, of which only 2 sequence types were present in Russia and European countries: NG-MAST 1407 (found in EU and Russia) and NG-MAST 4186 (one specimen from Sweden). The rest 63 molecular types were unique to Japan.

In order to establish a phylogenetic relationship between Russian and European clinical isolates of $N$. gonorrhoeae, a maximum likelihood phylogenetic tree was constructed. The phylogenetic tree colored according to the presence of NGMAST type in each country is shown in Fig. 1.

The analysis of sequence types distribution on the tree for the isolates from Russia and EU identified 16 clades with bootstrap values higher than $90 \%$ (Fig. 1). Some clades fully or partially corresponded to the European genogroups established for N. gonorrhoeae samples collected in Europe in 2013 in the report of the European center for disease prevention and control [6].

Clade $\alpha$ (bootstrap value $=100$ ) comprises 40 NG-MASTtypes (82 isolates) from 17 European countries and Russia; of them 6 sequence types are represented by 7 Russian isolates (8.5\%). The clade also includes sequence type 5624 (represented by 15 specimens from 7 countries) and corresponds to the previously described European genogroup G5624 [6].

Clade $\beta$ (bootstrap value $=94$ ) is formed by 33 sequence types (91 isolates), including type 225 commonly found in Europe (24 specimens from 12 European countries) and type 292 (15 specimens from 6 countries; of those specimens, one comes from Russia). Russian contribution to this clade is represented by 19 isolates (21.3\%) belonging to 12 different sequence types. Clade $\beta$ corresponds to the European genogroup G225 [6].

Clade $\Upsilon$ (bootstrap value $=96$ ) is constituted by 14 sequence types (98 isolates) collected in 17 European countries ( 1 isolate comes from Russia), of them 78 isolates represent sequence type 2992, which is the second most common NG-MAST type in Europe. Clade $\Upsilon$ corresponds to the European genogroup G2992 [6].

Clade $\delta$ (bootstrap value $=98$ ) comprises 3 sequence types (Portugal, Norway, UK). Clade $\varepsilon$ (bootstrap value = $100)$ consists of 4 sequence types (4 isolates from Norway, Greece and UK). Clade $\zeta$ (bootstrap value $=100$ ) contains only sequence types unique to Russia (7 specimens representing 5 NG-MAST types).

Clades $\eta$ and $\theta$ (bootstrap values 98 and 90, respectively) contain only European sequence types not found in Russia. Clade $\eta$ is formed by 9 NG-MAST types (16 samples), clade $\theta$ consists of 11 sequence types (34 samples). NG-MAST-types of these 2 clades represent the European genogroup G5333 [6].

Clade $\mathrm{(bootstrap} \mathrm{value}=98$ ) consists of 4 sequence types (4 samples collected in Portugal, Italy and the Netherlands).

Clade K (bootstrap value $=94$ ) comprises 4 European sequence types (36 samples), including sequence type 4995 (the fourth most common type in Europe found in 10 European countries) represented by 31 isolates. Clade $\mathrm{K}$ corresponds to the European genogroup G4995 [6].

Clade $\lambda$ (bootstrap value $=95$ ) includes 3 sequence types from European countries represented by 10 samples, of which 8 represent NG-MAST type 5441 detected in 5 countries.

Clade $\mu$ (bootstrap value $=94$ ) comprises 4 sequence types (10 samples from Greece, Denmark, Slovenia, and Portugal). Clade $v$ (bootstrap value $=98$ ) is formed by 3 sequence types (5 samples from 5 European countries). 
Table 2. NG-MAST types most common to EU and Japan

\begin{tabular}{|c|c|c|c|c|}
\hline Country (ID) & Year & $\begin{array}{l}\text { Number of analyzed clinical isolates } \\
\text { (number of identified sequence types) }\end{array}$ & $\begin{array}{l}\text { The most common } \\
\text { sequence types }\end{array}$ & $\begin{array}{l}\text { Proportion of samples } \\
\text { representing a specified } \\
\text { sequence type, \% }\end{array}$ \\
\hline Austria (AT) & 2013 & $50(24)$ & $\begin{array}{c}3785^{\star} \\
11575^{\star} \\
387,4994\end{array}$ & $\begin{array}{c}18.0 \\
12.0 \\
8.0 \text { each }\end{array}$ \\
\hline Belgium (BE) & 2013 & $55(24)$ & $\begin{array}{c}1407 \\
387,2992 \\
2400,5624\end{array}$ & $\begin{array}{c}16.4 \\
14.5 \\
7.3 \text { each }\end{array}$ \\
\hline Cyprus (CY) & 2013 & $6(4)$ & $\begin{array}{c}1407 \\
4269,6146^{\star}, 10803^{*}\end{array}$ & $\begin{array}{c}49 \\
17.0 \text { each }\end{array}$ \\
\hline Germany (DE) & 2013 & $45(30)$ & $\begin{array}{c}4995 \\
359,5441,9500^{*}\end{array}$ & $\begin{array}{c}8.9 \\
6.7 \text { each }\end{array}$ \\
\hline Denmark (DK) & 2013 & $54(28)$ & $\begin{array}{l}1993 \\
1407 \\
2400\end{array}$ & $\begin{array}{l}20.4 \\
14.8 \\
7.4\end{array}$ \\
\hline Spain (ES) & 2013 & $110(64)$ & $\begin{array}{c}1407 \\
2400 \\
21\end{array}$ & $\begin{array}{l}10.0 \\
9.1 \\
7.3\end{array}$ \\
\hline France (FR) & 2013 & $56(40)$ & $\begin{array}{c}645 \\
4995,5624,11352^{*}\end{array}$ & $\begin{array}{c}8.9 \\
5.4 \text { each }\end{array}$ \\
\hline Greece (GR) & 2013 & $48(20)$ & $\begin{array}{c}3128 \\
225,4730,11055^{\star}\end{array}$ & $\begin{array}{c}18.8 \\
10.4 \text { each }\end{array}$ \\
\hline Hungary (HU) & 2013 & $46(20)$ & $\begin{array}{c}1407 \\
995 \\
387,11046^{\star}\end{array}$ & $\begin{array}{c}21.7 \\
13.0 \\
6.5 \text { each }\end{array}$ \\
\hline Ireland (IE) & 2013 & $44(26)$ & $\begin{array}{c}2992 \\
384 \\
21,225,437,649^{\star}, 2400,10843^{\star}, 10846^{\star}\end{array}$ & $\begin{array}{c}15.9 \\
11.4 \\
4.5 \text { each }\end{array}$ \\
\hline Iceland (IS) & 2013 & $5(5)$ & $1034,2400,9541^{*}, 10640^{*}, 11080^{*}$ & 20.0 each \\
\hline Italy (IT) & 2013 & $24(13)$ & $\begin{array}{c}2992 \\
6360 \\
5624,8826^{\star}\end{array}$ & $\begin{array}{c}33.3 \\
12.5 \\
8.3 \text { each }\end{array}$ \\
\hline Latvia (LV) & 2013 & $38(15)$ & $\begin{array}{c}5 \\
10828^{*} \\
21,4269\end{array}$ & $\begin{array}{c}36.8 \\
13.2 \\
7.9\end{array}$ \\
\hline Malta (MT) & 2013 & $20(10)$ & $\begin{array}{c}2992 \\
1407,484^{\star}, 9905^{\star}, 10788^{\star}\end{array}$ & $\begin{array}{c}35.0 \\
10.0 \text { each }\end{array}$ \\
\hline Netherlands (NL) & 2013 & $66(38)$ & $\begin{array}{c}2992 \\
2400 \\
4995,5624,8154,8919\end{array}$ & $\begin{array}{c}13.6 \\
12.1 \\
4.5 \text { each }\end{array}$ \\
\hline Norway (NO) & 2013 & $55(41)$ & $\begin{array}{l}1407 \\
4275 \\
2400 \\
\end{array}$ & $\begin{array}{l}9.1 \\
7.3 \\
5.5 \\
\end{array}$ \\
\hline Portugal (PT) & 2013 & $103(54)$ & $\begin{array}{l}1407 \\
7445 \\
1034\end{array}$ & $\begin{array}{c}16.5 \\
11.7 \\
4.9\end{array}$ \\
\hline Sweden (SE) & 2013 & $49(31)$ & $\begin{array}{c}5445 \\
3128,7164,7445\end{array}$ & $\begin{array}{c}10.2 \\
6.1 \text { each }\end{array}$ \\
\hline Slovenia (SI) & 2013 & $53(26)$ & $\begin{array}{c}21 \\
10800,10801^{\star} \\
10798^{\star}, 10799^{\star}\end{array}$ & $\begin{array}{c}13.2 \\
11.3 \text { each } \\
7.5 \text { each }\end{array}$ \\
\hline Slovakia (SK) & 2013 & 38 (19) & $\begin{array}{c}1407,10800,11042^{*} \\
359,2992\end{array}$ & $\begin{array}{l}13.2 \text { each } \\
10.5 \text { each }\end{array}$ \\
\hline UK (UK) & 2013 & $106(52)$ & $\begin{array}{c}2992 \\
51 \\
4995\end{array}$ & $\begin{array}{c}11.3 \\
10.4 \\
6.6\end{array}$ \\
\hline Poland (PL) $)^{\star \star}$ & 2012 & - & $\begin{array}{c}1407 \\
8391^{\star} \\
1861,2992\end{array}$ & $\begin{array}{c}47.0 \\
7.0 \\
5.0 \text { each }\end{array}$ \\
\hline Japan (JP) & 2015 & 206 (65) & $\begin{array}{c}5687^{*} \\
1407 \\
6778^{\star}\end{array}$ & $\begin{array}{l}7.8 \\
6.3 \\
4.4\end{array}$ \\
\hline
\end{tabular}

Note: * — NG-MAST types unique to the specified country; ${ }^{* *}$ — NG-MAST types common to Poland and described in [17] 
Clade $\xi$ (bootstrap value $=100)$ consists of 3 sequence types (4 samples from Ireland and Denmark). Clade o (bootstrap value $=98$ ) is formed by 5 NG-MAST types (17 samples), including types 1993 and 5714 that are frequently found in Russia.

Clade $\pi$ (bootstrap value $=97$ ) includes 7 sequence types (12 isolates) found both in Russia and European countries. Those include sequence types 5792, 9485, 9490, and 9491, all of which are unique to Russia.

In each analyzed country there were isolates representing unique sequence types not found in any other country. For European countries, the proportion of isolates representing unique sequence types (relative to the total number of isolates in a given country) varied between 25 and 56\%. The lowest proportion was observed in the UK and Belgium, the highest, in Austria, Slovenia and Sweden (> 50\%). In Russia and Japan, the proportion of unique sequence type isolates exceeded 80\% (Table 3).

To identify groups with similar distribution patterns for unique sequence types and their relationship with the population size in a country of interest, cluster analysis was carried out. Twenty-one countries were included in the analysis (Table 3). Cyprus and Iceland were excluded due to the small number of isolates available (6 and 5 , respectively). After applying Ward's agglomerative hierarchical clustering procedure, the optimal number of clusters was determined in NbClust for $\mathrm{R}$ using the majority rule. Nine out of 30 methods (Silhouette, Duda, PseudoT2, Beale, Ratkowsky, PtBiserial, McClain, Dunn, SDindex) showed that the optimal number of clusters was 2 (bootstrap value $=0.01$ ); 6 methods (Hartigan, Scott, Marriot, TrCovW, TraceW, Ball) showed that the optimal number of clusters was 3 . Following the majority rule, it was decided that two clusters were the optimal choice; at the same time there was a statistically based rationale for breaking down cluster 2 into 2 sub-clusters (Fig. 2A).

Cluster 1 included Russia and Japan (countries with a population size of over 125 million people). Cluster 2 comprised all European countries with a population size from 0.4 to 81 million. Cluster 2 was divided into 2 subclusters: $2 \mathrm{a}$ and $2 \mathrm{~b}$. Subcluster 2 a was composed of the UK, Germany, Spain, Italy, and France (countries with a population size of 47-81 million); subcluster 2b included European countries with populations below 17 million (Ireland, Norway, Denmark, Slovakia, Malta,

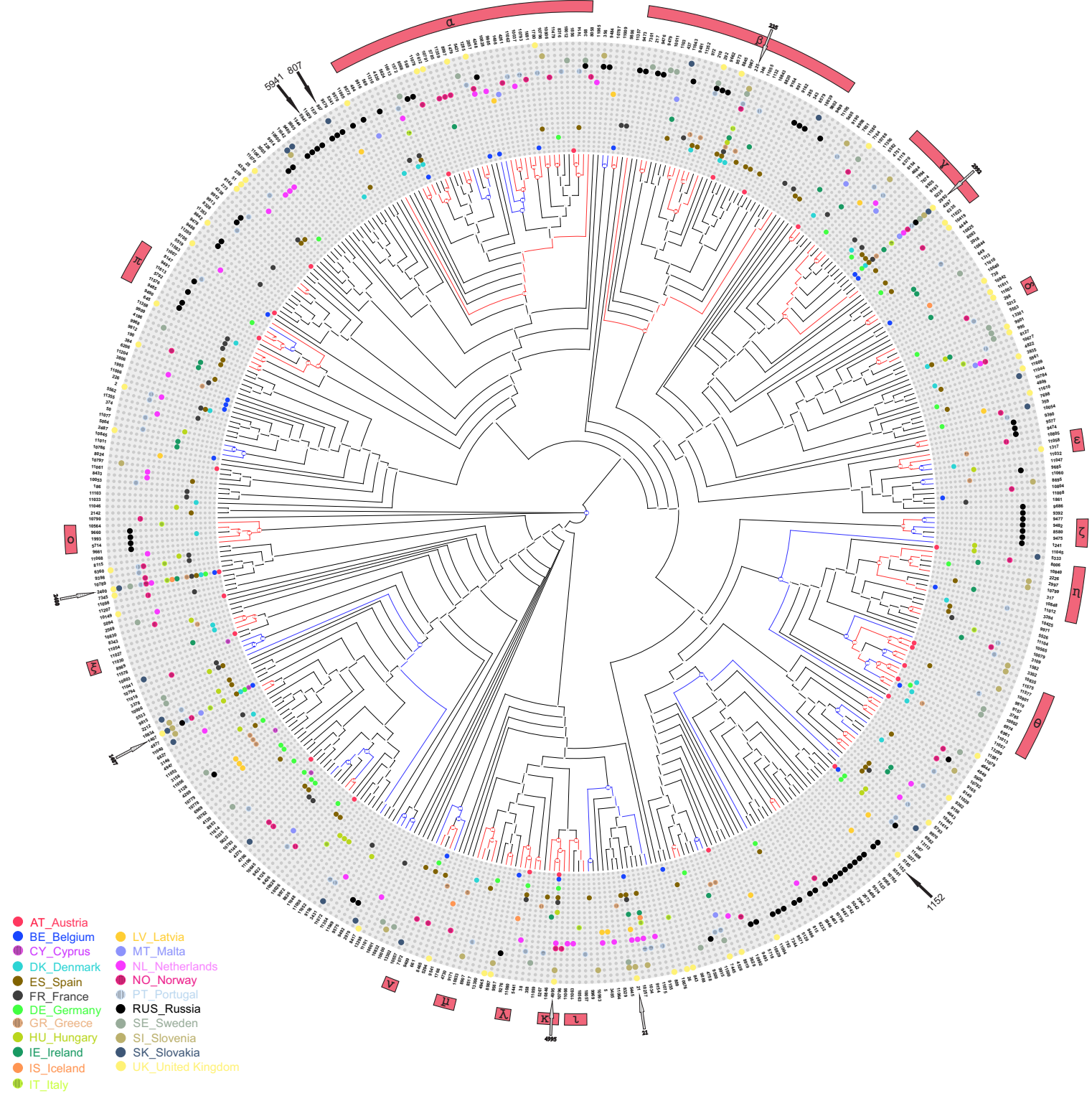

Fig. 1. A phylogenetic tree of N. gonorrhoeae NG-MAST types detected in Russia and EU. Branches with bootstrap values of $80-89$ are shown in blue; red indicates bootstrap value of 90-100. Phylogenetic clades (bootstrap values $\geq 90 \%$ ) are designated by Greek letters $\alpha-\pi$. Black arrows indicate NG-MAST types that are most common in Russia. Gray dashed arrows indicate NG-MAST types that are most common in European countries 
Latvia, Slovenia, Netherlands, Belgium, Portugal, Greece, Austria, Hungary, Sweden).

In general, the greater was the population size, the more isolates of unique sequence types were present in the country, as demonstrated by the countries with a population size over 47 million included in cluster 1 and subcluster 2a (Fig. 2B). This pattern was not observed for the countries with smaller population sizes constituting cluster $2 \mathrm{~b}$. Transition from cluster 2 to cluster 1 occurred for the countries with the population size over 125 million (Russia, Japan).

It was also interesting to analyze the contribution of migration to the distribution of unique sequence types across different countries. If only net migration rates and proportion of isolates of unique sequence types were analyzed, we were unable to find statistically significant clusters. When 3 parameters were included in the analysis (migration, population size and the proportion of unique sequence types), the agglomerative coefficient was 0.83 , which is lower than 0.93 , the value yielded by the analysis of 2 parameters (population size and the proportion of unique sequence types).

\section{DISCUSSION}

The comparative analysis of $N$. gonorrhoeae molecular typing data revealed significant differences between Russian, European and Japanese gonococcal populations. The majority of Russian isolates belonged to the sequence types that were not detected in European countries or Japan in the analyzed period. In Russia, only $3(0.4 \%)$ isolates represented the epidemiologically significant sequence type 1407, which prevailed in Belgium, Hungary, Denmark, Spain, Norway Portugal, Slovakia, and Japan. It is worth mentioning that in 2010 this sequence type amounted to over $10 \%$ of all isolates in many European countries, including Austria, Belgium, UK, Netherlands, Spain, Italy, Portugal, Romania, Slovenia,

Table 3. Distribution of isolates of unique NG-MAST types (2013) and Poland [15-17], as well as Japan and USA [18, 19]. This sequence type poses a great threat because it carries multiple determinants of antimicrobial resistance, including the mosaic penicillin-binding protein PBP2 and a mutation of the Ala501 residue in PBP2, both of which cause resistance to cephalosporins [16, 20, 21].

In the Russian dataset, there were only $3(0.4 \%)$ N. gonorrhoeae isolates representing sequence type 2992 and $7(0.9 \%)$ isolates representing type 2400 . Those sequence types were second and third most common types in Europe in 2013 (7.0 and 4.7\%, respectively). By contrast, types 228, 5714 , and 1751 were not detected in the European population, although they were highly prevalent in the Russian population.

For Poland, NG-MAST data were retrieved from [17], as they were missing in the EUROGASP database. The distribution of NG-MAST types in Poland was closer to that in European Union than in Russia; the Polish gonococcal population was dominated by sequence type 1407 (Table 2).

The analysis of the phylogenetic tree constructed for NGMAST types of clinical isolates collected in Europe and Russia reveals that $N$. gonorrhoeae populations are heterogenous both in Russia and Europe. There are sequence types that are present in many countries; at the same time, isolates coming from one and the same country can belong to phylogenetically distant clades. The most common European sequence types (NG-MAST 1407, 2992, 2400, 4995, 21, 225) that amount to the total of $25.9 \%$ of all European strains are phylogenetically distant from each other and distributed throughout the entire tree. Notably, there is no close relationship between the most common European sequence types and Russian sequence types, including NG-MAST 807, 1152 and 5941. Sixteen clades of the tree are characterized by high bootstrap values and partially or fully correspond to the European genogroups [6].

Further phylogenetic analysis of NG-MAST types drove us to the conclusion that geographically distant populations

\begin{tabular}{|c|c|c|c|c|c|}
\hline Country & $\begin{array}{l}\text { Number of unique } \\
\text { sequence types }\end{array}$ & $\begin{array}{l}\text { Number of isolates of unique } \\
\text { sequence types }\end{array}$ & $\begin{array}{c}\text { Proportion of isolates of unique } \\
\text { sequence types relative to the total } \\
\text { number of isolates, \% }\end{array}$ & $\begin{array}{l}\text { Population, } \\
\text { thousand }\end{array}$ & Net migration rate \\
\hline Russia & 73 & 129 & 80.6 & 142500 & 1.69 \\
\hline Japan & 63 & 192 & 93.2 & 126920 & 0 \\
\hline Germany & 15 & 18 & 40.0 & 81147 & 0.89 \\
\hline France & 24 & 27 & 48.2 & 65952 & 1.10 \\
\hline UK & 24 & 27 & 25.5 & 63396 & 2.57 \\
\hline Italy & 6 & 7 & 29.2 & 61482 & 4.47 \\
\hline Spain & 31 & 36 & 32.7 & 47370 & 6.14 \\
\hline Netherlands & 18 & 19 & 28.8 & 16805 & 1.99 \\
\hline Portugal & 32 & 40 & 38.8 & 10799 & 2.82 \\
\hline Greece & 10 & 21 & 43.8 & 10773 & 2.32 \\
\hline Belgium & 13 & 14 & 25.5 & 10444 & 1.22 \\
\hline Hungary & 10 & 14 & 30.4 & 9939 & 1.36 \\
\hline Sweden & 19 & 25 & 51.0 & 9119 & 1.64 \\
\hline Austria & 13 & 28 & 56.0 & 8222 & 1.78 \\
\hline Denmark & 14 & 17 & 31.5 & 5556 & 2.30 \\
\hline Slovakia & 9 & 13 & 34.2 & 5488 & 0.28 \\
\hline Ireland & 12 & 15 & 34.1 & 4776 & 2.51 \\
\hline Norway & 20 & 21 & 38.2 & 4723 & 1.68 \\
\hline Latvia & 11 & 16 & 42.1 & 2178 & -2.36 \\
\hline Slovenia & 14 & 27 & 50.9 & 1993 & 0.38 \\
\hline Malta & 5 & 8 & 40.0 & 411 & 1.99 \\
\hline
\end{tabular}


A

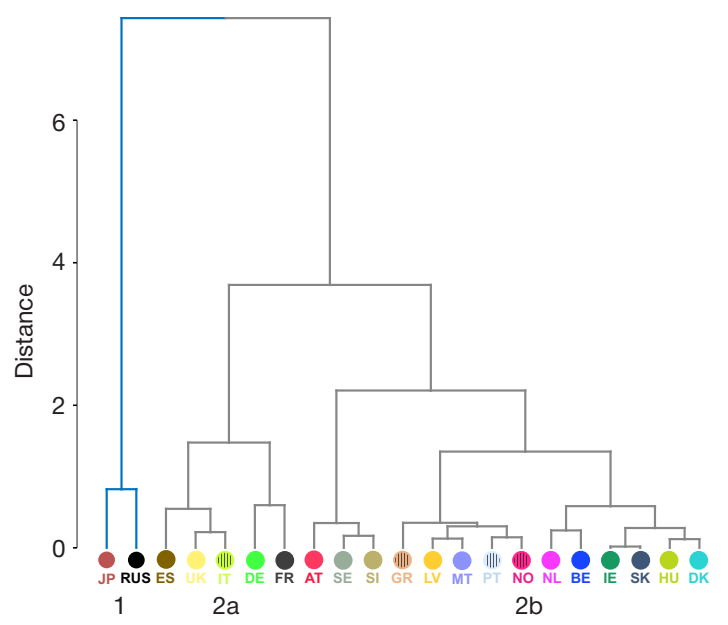

B

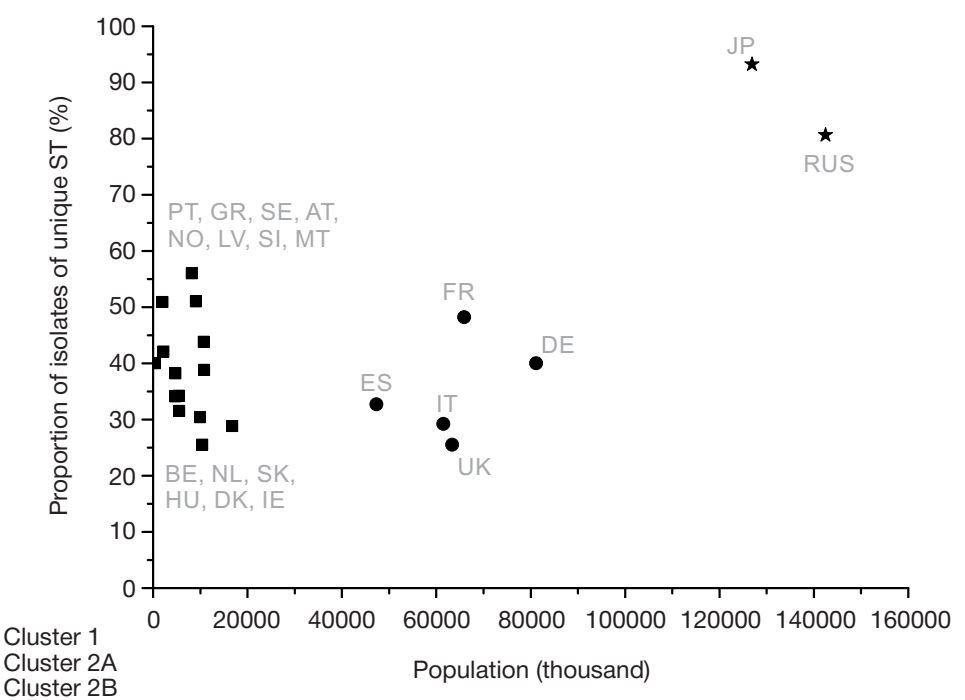

Fig. 2. Associations between the proportion of $N$. gonorrhoeae isolates of unique sequence types and the country population size. Country codes are given in Table 1. A. A dendrogram. The clusters are indicated by numbers. B. The relationship between the proportion of $N$. gonorrhoeae clinical isolates representing unique sequence types and the population size

of $N$. gonorrhoeae evolve more or less locally. This could be one of the reasons underlying the difference in the incidence of gonococcal infection in Russian and EU [22]: in Russia, the incidence of the infection is declining $[9,23]$ and there are no isolates resistant to ceftriaxone (the primary drug for gonorrhea treatment) $[9,10]$.

We have analyzed the associations between the proportion of isolates of unique sequence types and the population size of the country of interest. In Russia and Japan, the majority of isolates (> 80\%) belonged to NG-MAST types unique to this country. The cluster analysis of the population size and the proportion of isolates belonging to unique sequence types detected in a country allowed us to identify two clusters: the first cluster included Russia and Japan (population over 125 million people), the second cluster included European countries with population between 0.4 and 81 million people. On the whole, there was a certain distribution pattern for unique sequence types: the greater the country's population, the higher the proportion of samples with unique sequence types.

\section{CONCLUSIONS}

NG-MAST typing of N. gonorrhoeae clinical isolates collected in Russia has demonstrated their significant difference from the gonococcal populations circulating in the EU and Japan. The Russian N. gonorrhoeae population was dominated by sequence types 807, 1152 and 5941, which occurred only sporadically in other countries; sequence types 228, 5714 and 1751 were not detected in Russia at all. Between 2013 and 2018, in Russia there were only 3 isolates of epidemically significant sequence type $1407(0.4 \%$ of the total samples under study). This type poses a serious threat because it carries multiple determinants of antimicrobial resistance and prevails in many European countries and Japan. The phylogenetic analysis of NG-MAST types for Russian and European isolates has demonstrated their high heterogeneity and genetic distance between common European and common Russian NG-MAST types, suggesting that the Russian population of N. gonorrhoeae has been forming and evolving locally.

The majority (> 80\%) of Russian and Japanese isolates are unique to the two countries. This number is higher than the proportion of isolates with unique sequence types in European countries. The cluster analysis of the proportion of isolates representing unique sequence types and the population size allowed us to identify two clusters: one cluster for Russia and Japan and another cluster for European countries. The following trend was observed for the countries with a total population size over 47 million (Spain, UK, Germany, Italy, France, Russia, Japan): the greater the population size, the higher the proportion of isolates representing unique sequence types. We were unable to establish an association between the proportion of isolates representing unique sequence types and the net migration rate.

Thus, the phylogenetic analysis has revealed a relative isolation of the currently existing Russian population of N. gonorrhoeae, which follows its own evolutionary patterns. Nevertheless, there is a need for continuous surveillance of the spread of gonococcal infection and antimicrobial resistance of N. gonorrhoeae in Russia. The objective of this surveillance is timely detection and effective elimination of globally spreading sequence types with multiple determinants of antimicrobial resistance.

\section{References}

1. Foxman B, Riley L. Molecular epidemiology: focus on infection. Am $J$ Epidemiol. 2001; 153 (12): 1135-41. DOI: 10.1093/aje/153.12.1135.

2. Tacconelli E, Carrara E, Savoldi A, Harbarth S, Mendelson M, Monnet DL, et al. Discovery, research, and development of new antibiotics: the WHO priority list of antibiotic-resistant bacteria and tuberculosis. Lancet Infect Dis. 2018; 18 (3): 318-27. DOl: 10.1016/S1473-3099(17)30753-3.

3. Unemo M, Dillon JA. Review and international recommendation of methods for typing Neisseria gonorrhoeae isolates and their implications for improved knowledge of gonococcal epidemiology, treatment, and biology. Clin Microbiol Rev. 2011; (24): 447-58. DOI: 10.1128/CMR.00040-10.

4. Town K, Bolt H, Croxford S, Cole M, Harris S, Field N, et al. Neisseria gonorrhoeae molecular typing for understanding 
sexual networks and antimicrobial resistance transmission: A systematic review. J Infect. 2018; (76): 507-14. DOl: 10.1016/j. jinf.2018.02.011.

5. Harris SR, Cole MJ, Spiteri G, Sánchez-Busó L, Golparian D, Jacobsson $S$, et al. Public health surveillance of multidrugresistant clones of Neisseria gonorrhoeae in Europe: a genomic survey. Lancet Infect Dis. 2018; 18 (7): 758-68. DOI: 10.1016/ S1473-3099(18)30225-1.

6. European Centre for Disease Prevention and Control. Technical Report. Molecular typing of Neisseria gonorrhoeae - a study of 2013 isolates. Stockholm: ECDC; 2018. Available from: https:// www.ecdc.europa.eu/sites/portal/files/documents/Molecular-typingN-gonorrhoeae-web.pdf.

7. Ilina EN, Oparina NY, Shitikov EA, Borovskaya AD, Govorun VM. Molecular surveillance of clinical Neisseria gonorrhoeae isolates in Russia. J Clin Microbiol. 2010; 48 (10): 3681-89. DOI: 10.1128/ JCM.00565-10.

8. Shpilevaya MV, Obraztsova OA, Chestkov AV. The use of current genotyping assay methods for Neisseria gonorrhoeae. Vestnik Dermatologii i Venerologii. 2015; (6): 33-40. DOI: 10.25208/00424609-2015-0-6-33-40. Russian.

9. Kubanov A, Solomka V, Plakhova X, Chestkov A, Petrova N, Shaskolskiy B, et al. Summary and trends of the Russian Gonococcal Antimicrobial Surveillance Programme, 20052016. J Clin Microbiol. 2019; 5 (6): e02024-18. DOI: 10.1128/ JCM.02024-18.

10. Shaskolskiy B, Dementieva E, Kandinov I, Filippova M, Petrova N, Plakhova X, et al. Resistance of Neisseria gonorrhoeae isolates to beta-lactam antibiotics (benzylpenicillin and ceftriaxone) in Russia, 2015-2017. PLoS One. 2019; 14 (7): e0220339. DOI: 10.1371/ journal.pone.0220339.

11. Vorobiev DV, Solomka VS, Plakhova KI, Deryabin DG, Kubanov AA. NG-MAST genotyping of Neisseria gonorrhoeae strains isolated in Russian Federation in 2012-2015. Journal of microbiology, epidemiology, immunobiology. 2016; (4): 42-51. Russian.

12. Martin IMC, Ison CA, Aanensen DM, Fenton KA, Sprat BG. Rapid sequence-based identification of gonococcal transmission clusters in a large metropolitan area. J Infect Dis. 2004; (189): 1497-505. DOI: 10.1086/383047.

13. Stamatakis A. Using RAXML to infer phylogenies. Curr Protoc Bioinformatics. 2015; 51 (1): 6.14.1-14.14. DOI: 10.1002/0471250953.bi0614s51.

14. Charrad M, Ghazzali N, Boiteau V, Niknafs A. NbClust: an R

\section{Литература}

1. Foxman B, Riley L. Molecular epidemiology: focus on infection. Am J Epidemiol. 2001; 153 (12): 1135-41. DOl: 10.1093/aje/153.12.1135.

2. Tacconelli E, Carrara E, Savoldi A, Harbarth S, Mendelson M, Monnet DL, et al. Discovery, research, and development of new antibiotics: the WHO priority list of antibiotic-resistant bacteria and tuberculosis. Lancet Infect Dis. 2018; 18 (3): 318-27. DOI: 10.1016/S1473-3099(17)30753-3

3. Unemo M, Dillon JA. Review and international recommendation of methods for typing Neisseria gonorrhoeae isolates and their implications for improved knowledge of gonococcal epidemiology, treatment, and biology. Clin Microbiol Rev. 2011; (24): 447-58. DOI: 10.1128/CMR.00040-10.

4. Town K, Bolt H, Croxford S, Cole M, Harris S, Field N, et al. Neisseria gonorrhoeae molecular typing for understanding sexual networks and antimicrobial resistance transmission: A systematic review. J Infect. 2018; (76): 507-14. DOI: 10.1016/j. jinf.2018.02.011.

5. Harris SR, Cole MJ, Spiteri G, Sánchez-Busó L, Golparian D, Jacobsson S, et al. Public health surveillance of multidrugresistant clones of Neisseria gonorrhoeae in Europe: a genomic survey. Lancet Infect Dis. 2018; 18 (7): 758-68. DOI: 10.1016/ S1473-3099(18)30225-1.

6. European Centre for Disease Prevention and Control. Technical Report. Molecular typing of Neisseria gonorrhoeae - a study of 2013 isolates. Stockholm: ECDC; 2018. Available from: https:// package for determining the relevant number of clusters in a data set. Journal of Statistical Software. 2014; 61 (6): 1-36, DOl: 10.18637/jss.v061.i06.

15. European Centre for Disease Prevention and Control. Technical Report. Molecular typing of Neisseria gonorrhoeae — results from a pilot study 2010-2011. Stockholm: ECDC; 2012. Available from: https://www.ecdc.europa.eu/sites/portal/files/media/en/publications/ Publications/201211109-Molecular-typing-gonorrhea.pdf.

16. Chisholm SA, Unemo M, Quaye N, Johansson E, Cole MJ, Ison CA, et al. Molecular epidemiological typing within the European Gonococcal Antimicrobial Resistance Surveillance Programme reveals predominance of a multidrug-resistant clone. Euro Surveill. 2013; 18 (3): pii 20358. DOI: 10.2807/ese.18.03.20358-en.

17. Mlynarczyk-Bonikowska B, Malejczyk M, Majewski S, Unemo M. Antibiotic resistance and NG-MAST sequence types of Neisseria gonorrhoeae isolates in Poland compared to the world. Postepy Dermatol Alergol. 2018; 5 (6): 346-51. DOI: 10.5114/ ada.2018.79780.

18. Shimuta K, Watanabe $Y$, Nakayama S, Morita-Ishihara T, Kuroki T, Unemo $\mathrm{M}$, et al. Emergence and evolution of internationally disseminated cephalosporin-resistant Neisseria gonorrhoeae clones from 1995 to 2005 in Japan. BMC Infect Dis. 2015; (15): 378. DOI: 10.1186/s12879-015-1110-x.

19. Pandori M, Barry PM, Wu A, Ren A, Whittington WL, Liska S, et al. Mosaic penicillin-binding protein 2 in Neisseria gonorrhoeae isolates collected in 2008 in San Francisco, California. Antimicrob Agents Chemother. 2009; (53): 4032-34. DOI: 10.1128/ AAC.00406-09.

20. Unemo M, Shafer WM. Antimicrobial resistance in Neisseria gonorrhoeae in the 21st century: past, evolution, and future. Clin Microbiol Rev. 2014; 27 (3): 587-613. DOl: 10.1128/CMR.00010-14.

21. Unemo M. Current and future antimicrobial treatment of gonorrhoea - the rapidly evolving Neisseria gonorrhoeae continues to challenge. BMC Infect Dis. 2015; (15): 364. DOI: 10.1186/s12879-015-1029-2.

22. European Centre for Disease Prevention and Control. Gonorrhoea Annual epidemiological report for 2017. Stockholm: ECDC; 2019. Available from: https://www.ecdc.europa.eu/sites/default/files/ documents/gonorrhoea-annual-epidemiological-report-2017.pdf.

23. Kubanova AA, Kubanov AA, Melekhina LE, Bogdanova EV. Results of work of dermatovenereologic healthcare organizations in 2016. Vestnik Dermatologii i Venerologii. 2017; (4): 12-27. DOI: 10.25208/0042-4609-2017-0-4-20-21. Russian.
www.ecdc.europa.eu/sites/portal/files/documents/Molecular-typingN-gonorrhoeae-web.pdf.

7. Ilina EN, Oparina NY, Shitikov EA, Borovskaya AD, Govorun VM. Molecular surveillance of clinical Neisseria gonorrhoeae isolates in Russia. J Clin Microbiol. 2010; 48 (10): 3681-89. DOI: 10.1128/ JCM.00565-10

8. Шпилевая М. В., Образцова О. А., Честков А. В. Использование методов генотипирования Neisseria gonorrhoeae. Вестник дерматологии и венерологии. 2015; (6): 33-40. DOI: 10.25208/0042-4609-2015-0-6-33-40.

9. Kubanov A, Solomka V, Plakhova X, Chestkov A, Petrova N Shaskolskiy B, et al. Summary and trends of the Russian Gonococcal Antimicrobial Surveillance Programme, 20052016. J Clin Microbiol. 2019; 5 (6): e02024-18. DOI: 10.1128/ JCM.02024-18.

10. Shaskolskiy B, Dementieva E, Kandinov I, Filippova M, Petrova N, Plakhova X, et al. Resistance of Neisseria gonorrhoeae isolates to beta-lactam antibiotics (benzylpenicillin and ceftriaxone) in Russia, 2015-2017. PLoS One. 2019; 14 (7): e0220339. DOI: 10.1371/ journal.pone.0220339.

11. Воробьев Д. В., Соломка В. С., Плахова К. И., Дерябин Д. Г., Кубанов A. A. NG-MAST генотипирование штаммов Neisseria gonorrhoeae, выделенных на территории Российской Федерации в 2012-2015 годах. Журнал Микробиологии, эпидемиологии и иммунобиологии. 2016; (4): 42-51. 
12. Martin IMC, Ison CA, Aanensen DM, Fenton KA, Sprat BG. Rapid sequence-based identification of gonococcal transmission clusters in a large metropolitan area. J Infect Dis. 2004; (189): 1497-505. DOI: 10.1086/383047.

13. Stamatakis A. Using RAxML to infer phylogenies. Curr Protoc Bioinformatics. 2015; 51 (1): 6.14.1-14.14. DOI: 10.1002/0471250953.bi0614s51.

14. Charrad M, Ghazzali N, Boiteau V, Niknafs A. NbClust: an R package for determining the relevant number of clusters in a data set. Journal of Statistical Software. 2014; 61 (6): 1-36, DOl: 10.18637/jss.v061.i06.

15. European Centre for Disease Prevention and Control. Technical Report. Molecular typing of Neisseria gonorrhoeae - results from a pilot study 2010-2011. Stockholm: ECDC; 2012. Available from: https://www.ecdc.europa.eu/sites/portal/files/media/en/publications/ Publications/201211109-Molecular-typing-gonorrhea.pdf.

16. Chisholm SA, Unemo M, Quaye N, Johansson E, Cole MJ, Ison CA, et al. Molecular epidemiological typing within the European Gonococcal Antimicrobial Resistance Surveillance Programme reveals predominance of a multidrug-resistant clone. Euro Surveill. 2013; 18 (3): pii 20358. DOI: 10.2807/ese.18.03.20358-en.

17. Mlynarczyk-Bonikowska B, Malejczyk M, Majewski S, Unemo M. Antibiotic resistance and NG-MAST sequence types of Neisseria gonorrhoeae isolates in Poland compared to the world. Postepy Dermatol Alergol. 2018; 5 (6): 346-51. DOI: 10.5114/ ada.2018.79780.
18. Shimuta K, Watanabe $Y$, Nakayama S, Morita-Ishihara T, Kuroki T, Unemo $\mathrm{M}$, et al. Emergence and evolution of internationally disseminated cephalosporin-resistant Neisseria gonorrhoeae clones from 1995 to 2005 in Japan. BMC Infect Dis. 2015; (15): 378. DOI: 10.1186/s12879-015-1110-x

19. Pandori M, Barry PM, Wu A, Ren A, Whittington WL, Liska S, et al. Mosaic penicillin-binding protein 2 in Neisseria gonorrhoeae isolates collected in 2008 in San Francisco, California. Antimicrob Agents Chemother. 2009; (53): 4032-34. DOI: 10.1128/ AAC.00406-09.

20. Unemo M, Shafer WM. Antimicrobial resistance in Neisseria gonorrhoeae in the 21st century: past, evolution, and future. Clin Microbiol Rev. 2014; 27 (3): 587-613. DOI: 10.1128/CMR.00010-14.

21. Unemo M. Current and future antimicrobial treatment of gonorrhoea - the rapidly evolving Neisseria gonorrhoeae continues to challenge. BMC Infect Dis. 2015; (15): 364. DOI: 10.1186/s12879-015-1029-2.

22. European Centre for Disease Prevention and Control. Gonorrhoea. Annual epidemiological report for 2017. Stockholm: ECDC; 2019. Available from: https://www.ecdc.europa.eu/sites/default/files/ documents/gonorrhoea-annual-epidemiological-report-2017.pdf.

23. Кубанова А. А., Кубанов А. А., Мелехина Л. Е., Богданова Е. В. Результаты деятельности медицинских организаций дерматовенерологического профиля, достигнутые в 2016 г. Вестник дерматологии и венерологии. 2017; (4): 12-27. DOI: 10.25208/0042-4609-2017-0-4-20-21. 